\title{
An evaluation of the genetic conditioning of evoking pain
}

\author{
Anna Beata Pacian ${ }^{1, A, C-F \oplus}$, Janusz Kocki ${ }^{2, A, E-F \oplus}$, Jolanta Pacian ${ }^{1, D-E \oplus}$, Monika Kaczoruk ${ }^{1,3, B-D \oplus}$, \\ Maria Bylina ${ }^{4, A-D \oplus}$, Paulina Kaczor-Szkodny ${ }^{3, C, E-F \oplus}$, Elżbieta Monika Galińska ${ }^{3, E-F \oplus,}$ \\ Teresa Kulik ${ }^{1, A, E-F}$, Lech Panasiuk ${ }^{3, E-F}$ \\ ${ }^{1}$ Department of Public Health, Medical University, Lublin, Poland \\ ${ }^{2}$ Department of Clinical Genetics, Chair of Clinical Genetics, Medical University, Lublin, Poland \\ ${ }^{3}$ Institute of Rural Health, Lublin, Poland \\ ${ }^{4}$ Graduate of the specialty Public Health, Medical University, Lublin, Poland \\ A - Research concept and design, B - Collection and/or assembly of data, C - Data analysis and interpretation, \\ $D$ - Writing the article, E-Critical revision of the article, F- Final approval of article
}

Pacian AB, Kocki J, Pacian J, Kaczoruk M, Bylina M, Kaczor-Szkodny P, Galińska EM, Kulik T, Panasiuk L. An evaluation of the genetic conditioning of evoking pain. Ann Agric Environ Med. 2020; 27(2): 274-278. doi: 10.26444/aaem/121068

\begin{abstract}
Introduction and objective. Pain is an integral element of the pathogenic process and sometimes determines its course. Disorders in pain sensation, as well as its lack, the pain threshold, and variability in sensation of the same pain stimuli as more or less intensive by different persons, may be genetically conditioned. The aim of the study is to examine genes in pathogenesis of chronic pain.

Materials and method. The study was conducted in a specially selected group of 31 persons: study group - 20 patients with chronic pain, and control group - 11 healthy individuals who did not experience pain. The control group of 11 healthy persons, compared with the study group, was the catalyst for determining the relative quantification (RQ) of gene expression. Biological material in the form of venous blood was collected from the study participants into the tubes containing anticoagulant EDTA KE/2.7 ml (ethylenediaminetetraacetic acid), preventing extracorporeal blood clotting.

Results. Analysis of expression of the examined genes showed over-expression of the DRD1 gene in patients experiencing chronic pain, which means that in these patients an increased number of dopamine D1 receptors encoded by this gene should be expected. The dopamine D1 receptor is a G-protein-coupled receptor which regulates (stimulates or inhibits) adenyl cyclase - the enzyme responsible for synthesis of cyclic AMP (cAMP). An increase in the concentration of cAMP in neurons enhances the sensation of pain.

Conclusions. The genes (DRD1, COMT, OPRK1, HCN2) have a significant role in the pathogenesis of chronic pain in various diseases; they can also influence the perception of pain. Knowledge of these genes can contribute to the development of effective methods of combating pain.
\end{abstract}

\section{Key words}

genetics, chronic pain, genes expression, DRD1 gene, molecular research

\section{INTRODUCTION}

Pain is an integral element of the disease process and sometimes determines its course. Despite the fact that throughout history medicine has managed to cope with many difficulties in relieving pain, in many cases patients continue to report to physicians for assistance due to chronic pain. The International Association for the Study of Pain defines pain as 'an unpleasant sensory and emotional experience associated with actual or potential tissue damage, or described in terms of such damage [1].' This definition means that pain has biological and psychological aspects because it is both a sensory and emotional phenomenon. For pain to appear there must occur an irritating agent to induce it. The psychosomatic character of pain means that it is a subjective sensation, experienced and interpreted based on the ontogenetic sensitivity of the body to the inflicted stimuli, and the personally acquired experiences of an individual, as well as social and cultural conditioning [2]. The primary function of

Address for correspondence: Monika Kaczoruk, Department of Public Health Medical University, Lublin

E-mail: monika.kaczoruk@gmail.com

Received: 12.12.2019; accepted: 20.04.2020; first published: 11.05 .2020 pain is provision of information and protection of the body against a danger that threatens it and which may lead to the impairment or even damage of particular organs and tissues [3]. Pain releases various psychological, motor, vegetative and hormonal mechanisms which protect against hazardous factors. Disorders in the sensation of pain, as well as its lack, the height of the pain threshold, and also the variability in experiencing the same pain stimuli as more or less intensive by different persons, may be genetically conditioned. These characteristics are transmitted in chromosomal areas which encode quantitative traits. This means that the variability of pain sensation results from the inheritance of various genes and their mutual correlations [4]. Evidence of the genetic background of pain may be the studies indicating the cooccurrence of, among others, irritable bowel syndrome (IBS), musculoskeletal pain, pelvic pain, and dry eye syndrome in identical pairs of twins possessing the same DNA.

Both the Council of Europe and the Steering Committee on Bioethics deal with the analysis of problems resulting from the development of genetics for humans. In addition, it is noteworthy that the Parliamentary Assembly of the Council of Europe adopted on 25 April 2001, Recommendation No. 1512 on the protection of the human genome by the Council 
of Europe [5], which draws attention to the provision of access to information for society and to conducting constant monitoring of the progress concerning the Human Genome Project[5]. The principle of protection of the human genome is also emphasized considering the fact that genetic information is the heritage of mankind. This is associated with a particular character of the human genome as a set of a specific type of information, which must be covered by protection against uncontrolled changes on the grounds of law. Also, Chapter IV of the European Convention on Bioethics in contains resolutions concerning non-discrimination, genetic tests, and intervention on the human genome and gender selection. Moreover, Article 13 provides for the possibility of intervention to modify the human genome for preventive, diagnostic or therapeutic purposes only 'if its aim is not to introduce any modification in the genome of any descendants'. Although Article 13 prohibits genetic embryo therapies leading to modification of the genetic characteristics in the offspring; nevertheless, genetic manipulation in germ cells is allowed [6]. In turn, the right to privacy has been guaranteed in Article 7 of the UNESCO Declaration on the Human Genome [7]. This rule can be exempted only when, firstly, there are circumstances provided for by law, and secondly, they must appear either in international public law or human rights law. The most important right for respecting private life regarding information pertaining to genetic health was clarified in Article 10 of the European Convention on Bioethics, and in Article 16 of the IV Additional Protocol to the European Convention on Bioethics, by implementation of the protection of personal data derived from a genetic test.

\section{OBJECTIVE}

The aim of the is to examine genes in the pathogenesis of chronic pain.

\section{MATERIAL S AND METHOD}

The study was conducted in a specially selected group of 31 patients. The study group were 20 patients with chronic pain, while the control group included 11 healthy individuals who did not experience pain. The control group vs. the study group of 11 healthy persons was the catalyst to determine the relative quantification (RQ) of expression of the examined genes. Biological material in the form of venous blood was collected from the study participants into tubes containing anticoagulant EDTA KE/2.7 ml (ethylenediaminetetraacetic acid), preventing extracorporeal blood clotting. The use of anticoagulants enables the performance of a whole blood test after its previous centrifugation in specified conditions and time.

The object of the study were the following genes: $D R D 1$, COMT, OPRK1, KCNK18, HCN2,B2M and GAPDH genes, as housekeeping reference genes. The methods and techniques applied in order to carry out genetic tests (analysis of expression of the DRD1, COMT, OPRK1, KCNK18, HCN2, $B 2 M$ genes) included the following:

- collection of the material (peripheral blood);

- isolation of lymphocytes from peripheral blood by of differential centrifugation and density gradient centrifugation;
- isolation of total RNA from lymphocytes using the method by Chomczyński and Sacchi;

- quantitative and qualitative analysis of RNA;

- synthesis of cDNA in inverse transcription reaction;

- analysis of gene expression by the Real-Time PCR method.

Analysis of the results of genetic tests was performed using the Expression Suite Software (Applied Biosystems). Analysis of expression of the examined genes was carried out regarding the reference gene GAPDH which shows a stable level of expression in a cell. The results obtained were presented in graphs.

Blood performs many biological functions, and its composition reflects the state of health of the body which is an important diagnostic factor in the process of treatment. Blood collected from the study participants was used for the isolation of lymphocytes. At the first stage, it was diluted with phosphate-buffered saline (PBS). The diluted blood was layered on Gradisol L (1 part of Gradisol - 2 parts of blood) and centrifuged in an Eppendorf Centrifuge 5810R at 3,000 revolutions/minute, for 30 minutes, at the temperature of $20^{\circ} \mathrm{C}$. The buffy coat produced as a result of centrifugation was collected using an automatic pipette into separate falcon tubes, and made up with PBS solution to the volume of $4 \mathrm{ml}$, subsequently centrifuged again in the Eppendorf Centrifuge $5810 \mathrm{R}$ at 1,600 at 600 revolutions/minute, for 10 minutes, at the temperature of $20^{\circ} \mathrm{C}$. After centrifugation, the supernatant was transferred into an Eppendorf Safe Lock Tubes then made up with PBS and centrifuged in an Eppendorf MiniSpin centrifuge at 1,600 revolutions/minute, for 10 minutes, at the temperature of $20^{\circ} \mathrm{C}$. After centrifugation, the fluids were drained off, leaving the residue of lymphocytes on the walls of the tube, and frozen at the temperature of $-80^{\circ} \mathrm{C}$, to await the subsequent stage of the study.

At the subsequent stage of the study, the RNA was isolated from lymphocytes using the TRISol (Total RNA Isolation) Total RNA Purification Kit (Sigma Aldrich) which is a mixture, among others, of phenol and guanidine isothiocyanate causing cell lysis and inactivation of endogenous RNase. Lymphocytes sediment was poured with $1 \mathrm{ml}$ of TRISol and homogenized using a pipette for complete fragmentation of the particles. Then, $200 \mu \mathrm{l}$ of chloroform was added, and the tubes shaken manually for 15 seconds and left at room temperature for 15 minutes. After this time elapsed, the tubes were centrifuged for another 15 minutes using the Eppendorf Centrifuge 5415R at 1,3200 revolutions per minute, at the temperature of $4^{\circ} \mathrm{C}$. Centrifugation led to the segregation of phases into 3 layers (RNA, DNA and proteins). RNA stopped in the upper aqueous phase and was transferred into new tubes. Into the transferred aqueous phase $500 \mu \mathrm{l}$ of isopropanol was added to each tube, mixed and left for 15 minutes at room temperature. The tubes were then centrifuged again at 1,3200 revolutions per minute. Supernatant was discharged, leaving RNA at the bottom of the tube in the form of sediment.

At the next stage, the sediment was diluted by the addition of $12 \mu \mathrm{l}$ of water into each tube, and $2 \mu \mathrm{l}$ of solution was drained off from each tube to examine the purity and concentration of RNA. The measurement was performed using the NanoDrop 2000c Spectophotometer Thermo Scientific. The purity of specimens remained within the standard range from $1.8-2 \mu \mathrm{g} / \mu \mathrm{l}$. Subsequently, the samples were diluted in water until the concentration of RNA in 
each tube was $1 \mu \mathrm{g}$. The RNA thus prepared was then used in the process of reverse transcription. For this procedure, Master Mix (Applied Biosystems) solution was prepared in 'on ice' conditions. Per each tube, $3.2 \mu \mathrm{l}$ of ultra pure water (RNase free) was used; $2 \mu$ l of buffer containing ions, maintaining proper $\mathrm{pH} ; 0.8 \mu \mathrm{l}$ of mixture of deoxynucleotides dNTPs $(100 \mathrm{mM}) ; 2 \mu \mathrm{l}$ of starters RT Random Primer; $1 \mu \mathrm{l}$ of RNase inhibitors, and $1 \mu \mathrm{l}$ of reverse transcriptase (RT) enzyme. Then, into each tube containing $10 \mu \mathrm{l}$ of RNA diluted in water and $10 \mu \mathrm{l}$ of Master Mix solution was added, and placed in a heating block Thermo Cycler Veriti 96 Well (Applied Biosystems) to perform reverse transcription.

At the first stage lasting 10 minutes, there occurred preliminary heating-up to the temperature of $25^{\circ} \mathrm{C}$. At the subsequent stage lasting 120 minutes, at the temperature of $37^{\circ} \mathrm{C}$ primers were attached, whereas at the next stage lasting or 5 minutes at the temperature of $85^{\circ} \mathrm{C}$, elongation occurred - reverse transcription using the RT (reverse transcriptase) enzyme. The final stage of reverse transcription was cooling down to the temperature of $4^{\circ} \mathrm{C}$.

The cDNA produced was subjected to the amplification process. This process was conducted by the method of Real Time - PCR (polymerase chain reaction) which consists in the synthesis of the fragments of cDNA and monitoring the reaction due to the phenomenon of fluorescence using TaqMan (Sigma Aldrich) probes containing sequences of nucleotides and fluorescent dye which emits a beam of light under the effect of ultraviolet radiation. The reaction is conducted in the Step One Plus Real-Time PCR System (Applied Biosystems) thermal cycler, in which the probes are heated up and cooled, depending on the type of gene replicated. Preparation of the tubes consisted in combining in each probe of $10 \mu \mathrm{l}$ of ultra pure water, deionized, DNase and RNase free, $12.5 \mu \mathrm{l}$ Master Mix (Applied Biosystems) the composition of which included: buffer, starters, free nucleotides, DNA polimerase and $1.25 \mu \mathrm{lDNA}$, as well as $1.25 \mu \mathrm{l}$ of previously mentioned TaqMan type probes for appropriate genes: DRD1, COMT, OPRK1, KCNK18, HCN2, B2M, GAPDH. Subsequently, the top of the plate was sealed with foil and shaken in the vortex IKA MS 3 basic (Sigma Aldrich), and centrifuged in the Eppendorf Concentrator 5301 centrifuge for mixing and placing the full content of the probes at their bottom. The plates prepared in this way were placed inae thermal cycler.

\section{RESULTS}

Analysis performed using the Q-PCR method showed expression of all the examined genes, with the exception of the KCNK18 gene. In the study group, relative quantification (RQ) of gene expression was as follows: DRD1 RQ = 40; OPRK1 RQ = 1.10; HCN2 RQ = 1.10; $\mathrm{B} 2 \mathrm{M}$ RQ = 1.8; COMT $\mathrm{RQ}=1.4$, whereas in the control group, RQ for all genes was 1. Relative quantification log10RQ of genes in the examined group was as follows: DRD1 $\log 10 \mathrm{RQ}=1.6$; COMT $\log 10=0.146 ; \mathrm{B} 2 \mathrm{M} \log 10=0.26 ; \mathrm{OPRK} 1 \log 10=0.587 ; \mathrm{HCN} 2$ $\log 10=0.062$.

The results obtained are presented in the form of graphs.

In peripheral blood lymphocytes in patients in the study group, a slightly higher expression of the OPRK1 gene was observed, compared to the control group (Fig. 1).

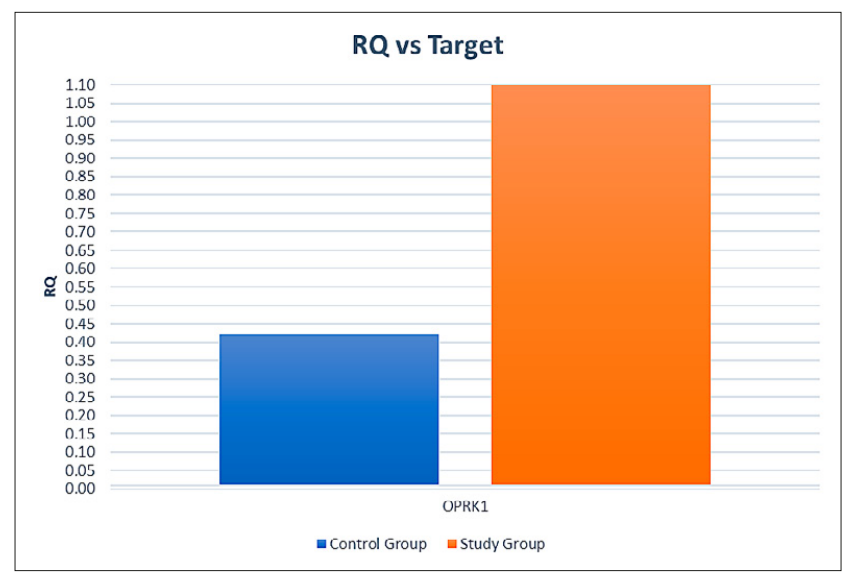

Figure 1. Comparison of RQ value for the OPRK1 gene between the study and control groups

In peripheral blood lymphocytes in patients in the study group, a higher expression of the DRD1 gene was observed, compared to the control group (Fig. 2).

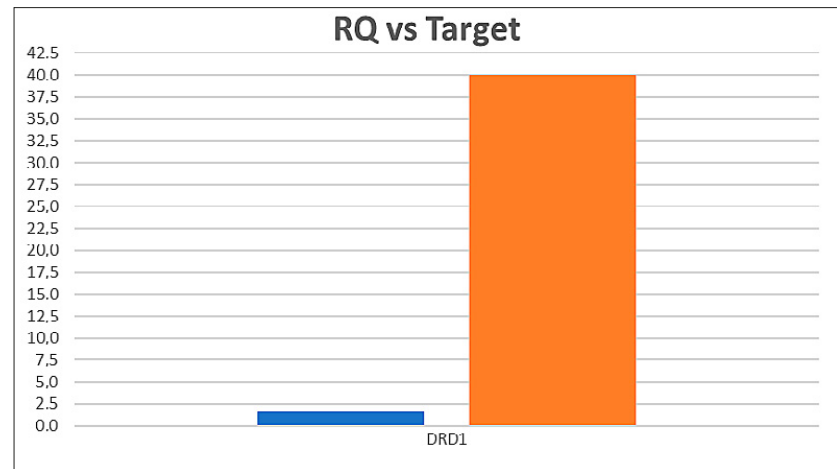

Figure 2. Comparison of RQ value for the DRD1 gene between the study and control groups

In peripheral blood lymphocytes in patients in the study group, the lack of expression of the KCNK18 gene was noted, compared to the control group where expression of this gene was observed (Fig. 3).

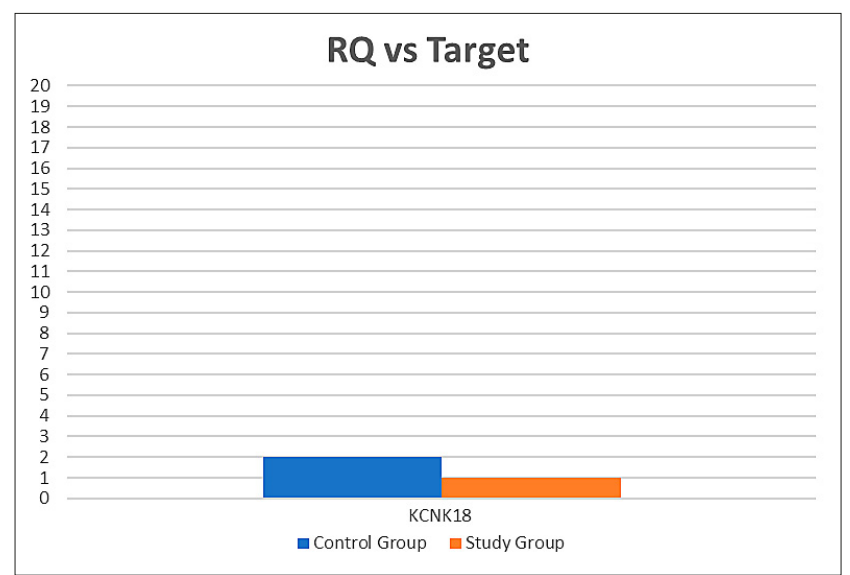

Figure 3. Comparison of $\mathrm{RQ}$ value for the KCNK18 gene between the study and control groups

In peripheral blood lymphocytes in patients in the study group a slightly higher expression of the COMT gene was observed, compared to the control group (Figure 4). 


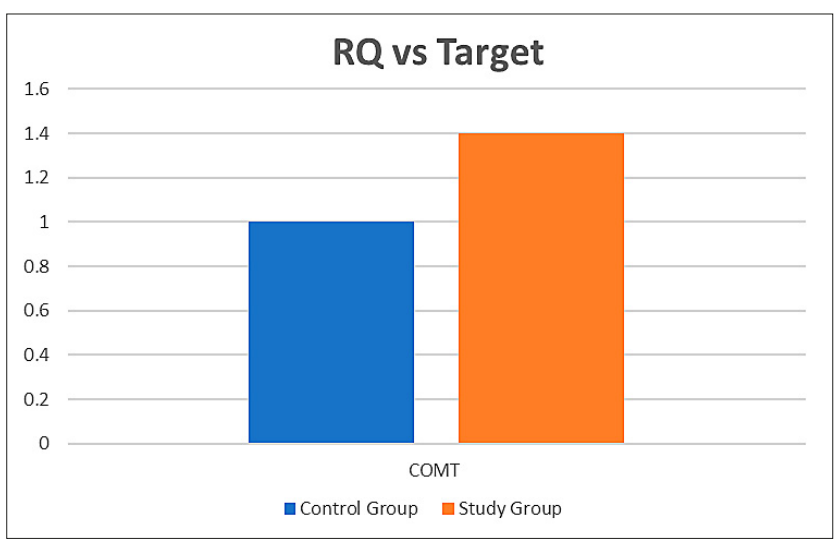

Figure 4. Comparison of $\mathrm{RQ}$ value for the COMT gene between the study and control groups

In peripheral blood lymphocytes in patients in the study group a slightly higher expression of the HCN2 gene was observed, compared to the control group (Fig. 5).

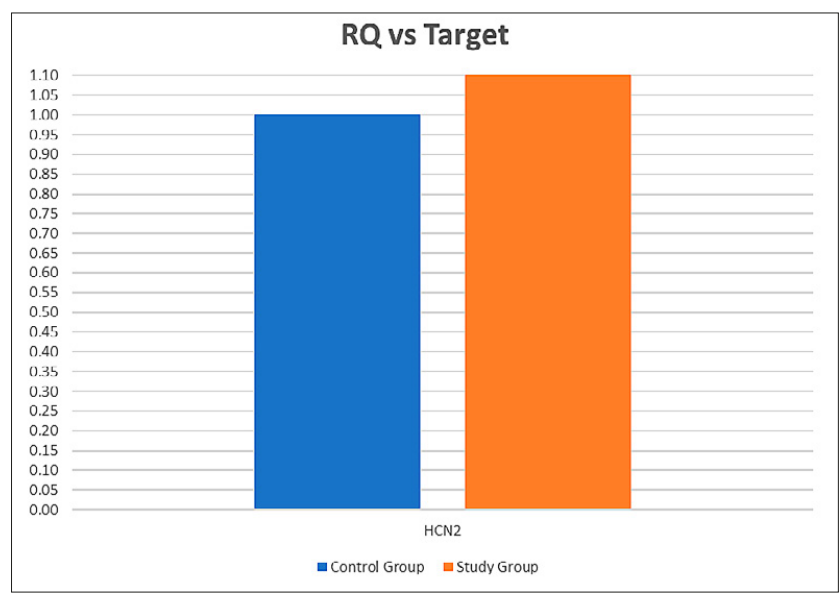

Figure 5. Comparison of $\mathrm{RQ}$ value of the HCN2 gene between the study and control groups

Analysis of expression of the examined genes showed an over-expression of the DRD1 gene in patients who experienced chronic pain, which means that in these patients an increased number of dopamine D1 receptors encoded by this gene should be expected. The dopamine D1 receptor is a G-proteincoupled receptor which regulates (stimulates or inhibits) adenyl cyclase - the enzyme responsible for synthesis of cyclic AMP (cAMP). An increase in the concentration of cAMP in neurons enhances the sensation of pain. Opioids interacting with $G$ protein inhibit adenyl cyclase activity, result in an analgesic effect. Adenyl cyclase may also be activated by an increased concentration of prostaglandins released at the site of inflammation. Non-steroid anti-inflammatory drugs (NSAIDs) inhibit the production of prostaglandins and cAMP.

\section{DISCUSSION}

The function of the KCNK18 gene plays a special role in pain sensation. The product of the gene is a potassium channel protein which equalizes resting membrane potential. The channel is directly activated by calcium signalling which activates the channel by calcineurin, and is inhibited by arachidonic acid and other naturally occurring unsaturated free fatty acids [8].

Another exceptionally important finding was identification of the gene labelled as HCN2, responsible for the perception of chronic pain of a non-receptor type. This gene is also responsible for the functioning of the sodium and potassium channels in nerve endings. Its removal or pharmacological blockage results in total elimination of neuropathic pain, with normal sensation of receptor pain. This finding is of unprecedented importance for patients suffering from chronic neuropathic pain, simultaneously enabling avoidance of accidental lesions signalled by acute pain [9].

Studies carried out in two different populations, 210 families from Finland and Australia, confirmed the genetic background of susceptibility to migraine. The mutation was identified, the presence of which may condition the occurrence of migraine headache. It was found that in the examined group of patients suffering from this disorder, the majority possessed mutation in the KCNK18 gene. Recent genetic studies of migraine proved that various types of pain accompanying migraine in different patients, i.e. throbbing or unilateral pain is more closely linked with the specified genetic loci than general pain. It is presumed that migraine and epilepsy may have a common genetic background. Studies showed that patients with epilepsy suffer headaches more often than others [10].

Another study concerned 113 patients with fibromyalgia and 65 healthy individuals, in whom four single nucleotide polymorphisms were genotyped. After completion of the study, the results obtained demonstrated unequivocally that the frequency of genetic changes related to low activity of the COMT enzyme was significantly higher in patients with fibromyalgia than in healthy individuals. This shows the great importance of the role of the COMT gene in experiencing sensitivity to pain in patients with fibromyalgia [11].

The study by Diatchenko et al., on 202 females aged 18 - 34, demonstrated that the COMT genotype is closely associated with the perception of pain. There are three major groups of haplotypes which specify the enzymatic COMT activity. The LPS haplotype is related to low sensitivity to pain, APS - with greater sensitivity, whereas HPS shows the greatest sensitivity. All three haplotypes constitute $11 \%$ of variability in pain perception. Also, COMT as an inhibitor shows a strong increase in sensitivity to pain. These data demonstrate that the activity of this gene exerts an effect on pain sensation and shows a strong relationship between genetic polymorphism and sensitivity to pain and the risk of occurrence of chronic pain [12]. The mechanisms of the effect of COMT on pain sensation is probably associated with the allele at codon 158 , which leads to reduction in the content of enkephalin at specified sites in the central nervous system connected with the sensation of pain. Another possibility is the reduction of the activity of COMT by elevation of catechyloamines, such as epinephrine, causing the production of permanent pain conditions by stimulation of beta-2-adrenergic receptors in the peripheral nervous system $[13,14]$.

The study conducted by Sato $\mathrm{H}$ et al. in a group of 50 volunteers, 22 females and 28 males aged 19 - 48, considering its small size was supposed to generate hypotheses. However, this study showed that genetic factors (in three opioid receptor genes, including OPRK) and gender are responsible for 34 $43 \%$ of variability in thermal and mechanical sensitivity to pain, thus confirming the effect of genetic variability in the perception of pain [15]. 
According to many clinical and pre-clinical studies, the effectiveness of opioids is related to genetic variability. The European Pharmacogenetic Opioid Study (EPOS), conducted in a group of 2,294 patients with cancer-related pain who were administered strong opioids for the treatment of pain caused by cancer, in which 112 SNPs in 25 genes were tested, including OPRK1, did not confirm any significant relationships, neither in the development nor in the validation analyses. The mean age of patients was 62.5 , whereas the mean pain intensity - $3.5[16,17]$.

The sensation of pain accompanies man many times throughout life, is present at birth as well as death, and any attempt to totally free oneself from pain seems to be an illusion. An acute, short-lasting pain can be relieved by available means; however, in its chronic forms such actions are not so effective. The problem of chronic pain becomes increasingly more common in the contemporary world due to the constant progress of civilisation, which is conducive to the occurrence of diseases of a chronic character.

Both the results of the presented study and those by other researchers allow the presumption that genes play an important role in evoking chronic pain. Therefore, further studies should be carried out which might explain the role of genes in the pathogenesis of the sensation of chronic pain. This is very important because gene studies could also contribute to the effectiveness of pain reduction by enabling the assessment of the effects of selected therapeutic techniques, or may hold promise as a target for new pain therapeutics [18, 19].

The study by Sabu James showed that pain treatment with gene(s) is unique - it might involve initiating 'de novo' expression of an 'anti-nociceptive' gene that is not normally present in the target cell or, decreasing the expression of an active 'pro-nociceptive' gene in those cells. James stated that gene therapy-based strategies could soon evolve as a novel approach to pain management, not only for cancer, but for pain associated with a number of other disorders [20]. As indicated by Grzybkowska et al., gene studies could also contribute to the effectiveness of pain reduction by people with depression. Depression frequently can cause unexplained pain, such as headaches or back pain, and people who are depressed might struggle to improve or maintain physical health. In turn, chronic pain can lead to difficulties with sleeping, increased stress, or feelings of guilt or worthlessness associated with depression. These influences can create a cycle that is difficult to break [21].

\section{CONCLUSIONS}

Analysis of expression of the DRD1, COMT, OPRK1, KCNK18, HCN2 genes in peripheral blood lymphocytes in patients with chronic pain confirmed an enhanced expression of four genes: DRD1, COMT, OPRK1, HCN2, compared to the control group. These genes have a significant role in the pathogenesis of chronic pain in various diseases. They can also influence the perception of pain. Knowledge of these genes can contribute to the development of effective methods of combating pain. The applied methods of treatment of chronic pain seem to be insufficient and ineffective. This inclines towards the search for new, multidimensional solutions in order to be able to fully and professionally help patients in the face of their suffering. In these actions, all available methods and means should be undertaken at various stages of medical interventions, from prophylaxis through treatment to rehabilitation and prevention of the negative effects of the diseases and complaints occurring, and not only alleviation of already existing pain. It is necessary to conduct further studies which may explain the role of these genes in the pathogenesis of the sensation of chronic pain.

\section{REFERENCES}

1. Cohen M, Quintner J, van Rysewyk S. Reconsidering the IASP definition of pain. Pain Reports. 2018. doi: 10.1097/PR9.0000000000000634

2. Hadjistavropoulos T, Craig KD, Duck S, Cano A, Goubert L, JacksonPL, et al. A Biopsychosocial Formulation of Pain Communication. Psychological Bulletin. 2011. doi: 10.1037/a0023876

3. Swift A. Understanding pain and the human body's response to it. Nursing Times. 2018; 114: 3, 22-26.

4. Klepstad P, Fladvad T, Skorpen F, Bjordal K, Caraceni A, Dale O, et al. Influence from genetic variability on opioid use for cancer pain: a European genetic association study of 2294 cancer pain patients. Pain. 2011; 152(5): 1139-1145.

5. Petrini C. Between altruism and commercialisation: some ethical aspects of blood donation. Ann Ist Super Sanità. 2013; 49 (4): 412-416. doi: 10.4415/ANN_13_04_16

6. Kołodyński P, Drab P. Prawne regulacje pobierania i transplantacji narządów oraz tkanek w ujęciu europejskiej konwencji bioetycznej. Przegl Europejski. 2016; 1: 52-65.

7. Henk AMJ, Michèle SJ. The UNESCO Universal Declaration on Bioethics and Human Rights: background, principles and application. United Nations. UNESCO 2009.

8. Egenberger B, Polleichtner G, Wischmeyer E, Döring F. N-linked glycosylation determines cell surface expression of two-pore-domain K+ channel TRESK. Biochem Biophys Res Commun. 2010; 391: 1262-7. doi: 10.1016/j.bbrc.2009.12.056

9. Emery EC, et al. "HCN2 Ion Channels Play a Central Role in Inflammatory and Neuropathic Pain". Science 2011;333: 1462-6. doi: 1126/science.12062435

10. Lafrenière RG, Cader MZ, Poulin JF, Andres-Enguix I, Simoneau M, Gupta N, et al. A dominant-negative mutation in the TRESK potassium channel is linked to familial migraine with aura. Nat Med. 2010; Oct: 16(10): 1157-60. doi: 10.1038/nm.2216. Epub 2010 Sep 26.

11. Martínez-Jauand M, Sitges C, Rodríguez V, Picornell A, Ramon M, Buskila D, Montoya P. Pain sensitivity in fibromyalgia is associated with catechol-O-methyltransferase (COMT) gene. Eur J Pain. 2013; 17(1): 16-27. doi: 10.1002/j.1532-2149.2012.00153.x

12. Edwards A. The human pain genetics database: an interview with Luda Diatchenko. Pain Manag. 2018; 1; 8(4): 259-261. doi: 10.2217/ pmt-2018-0028

13. Fillingim RB, Wallace MR, Herbstman DM, Ribeiro-Dasilva M, Staud R. Genetic contributions to pain: a review of findings in humans. Oral Dis. 2008; 14(8): 673-82. doi: 10.1111/j.1601-0825.2008.01458.x

14. Fillingim RB. Individual differences in pain: understanding the mosaic that makes pain personal. Pain. 2017; 158(1): 11-18. doi: 10.1097/j. pain.0000000000000775

15. Sato H, Droney J, Ross J, Olesen AE, Staahl C, Andresen T, et al. Gender, variation in opioid receptor genes and sensitivity to experimental pain. Mol Pain 2013; 9: 20. doi: 10.1186/1744-8069-9-20

16. Branford R, Droney J, Ross JR. Opioid genetics: the key to personalized pain control? Clin Genet. 2012; 82: 301-310.

17. Klepstad P, Fladvad T, Skorpen F, et al. Influence from genetic variability on opioid use for cancer pain: a European genetic association study of 2294 cancer pain patients. Pain. 2011; 152(5): 1139-1145.

18. Półrola P, Wilk-Franczuk M, Wilczyński J, Nowak-Starz G, GóralPółrola J, Chruściński G, et al. Anti-inflammatory effect on genes expression after four days of Qigong training in peripheral mononuclear blood cells in healthy women. Ann Agric Environ Med. 2018; 25(2): 329-333. doi: https://doi.org/10.26444/aaem/85208

19. Chen YC, Auer-Grumbach M, Matsukawa S, Zitzelsberger M, Themistocleous AC, Strom TM, et al. Transcriptional regulator PRDM12 is essential for human pain perception. Nat Genet. 2015; 47(7): 803-8. doi: 10.1038/ng.3308

20. James S. Human pain and genetics: some basics. Br J Pain. 2013; 7(4): 171-178. doi: 10.1177/2049463713506408

21. Grzybkowska A, Anczykowska K, Pyczek JM, Żychowska M. Increased levels of interleukin-10 expression compared to interleukin- 6 in leukocytes of healthy subjects. Could it be useful in the future of the depression diagnosis? Acta Neuropsychol. 2018; 16(3): 243-248. doi: 10.5604/01.3001.0012.4886 